TEXT Vol 20 No 2 (October 2016)

\title{
Poetry and prose contents
}

- Dominique Hecq, What it's like to be too much page 2

- Rachel Hennessy, The (in)exactitude of knowledge page 4

- Lynn Davidson, A roof over my head page 13

- Toni Roberts, Making with mud and my mother page 17

- Jane Downing, Let them eat brioche page 26

- Craig Jordan-Baker, The death of Patrice Nacullian page 31 


\title{
Dominique Hecq
}

\section{What it's like to be too much}

\author{
after Patricia Smith
}

First of all it's having your first smoke at three

It's pinching cherry lollies from your mother's cupboard

It's answering back and biting your best friend

It's eavesdropping and blushing and sweating and stuttering like a wood-pecker

It's sanding your face to erase your freckles

It's adding numbers and stringing words together for dolls on death-row

It's scribbling on the neighbour's wall with chalk-sticks screeching on red

bricks

It's kissing boys behind the church

It's gobbling up words without spilling any like they are milk and honey

It's leaving

It's hacking off your mother tongue and tending the wound with foreign words It's nicking sounds and cadences to patch up sheets of language

It's hobby-horsing at the Corporate Institute of Excellence where Outlook

stares at you

like a

sentinel

It's tumbling down the waterfall of your mind like your name

is Niagara when you call

yourself Artaud and scream and scream and scream

It's your feet dragging and your body leaving you

It's Bedlam Hollywood style with millions of live eyes lining the walls

It's the hand of god popping pink pills purple pillows paper white pilgrims in your gob

It's running away like some joker except the joke is on you

It's bursting into tears as wattle showers you whole with sunshine

Finally it is writing

Dominique Hecq has published five books of poetry, including Good Grief (2000), The silence of the gaze (2001) and Couchgrass (2007). Her recent work increasingly pursues polygeneric concerns - see Out of

Bounds (2009) and Stretchmarks of Sun (2014). Hush pushes this formal 
concern even further and will be published next year. Swarm, Duel and Envol d'aube are in preparation.

\section{TEXT}

Vol 20 No 2 October 2016

http://www.textjournal.com.au

General Editor: Nigel Krauth. Editors: Kevin Brophy \& Enza Gandolfo Creative works editor: Anthony Lawrence

text@textjournal.com.au 


\section{Rachel Hennessy}

\section{The (in)exactitude of knowledge}

\section{The lecturer (1)}

He sticks his head into the hall and asks 'Is this Biology 101?' before ambling into the lecturing space. The students (off screen) titter. Who is this crazy guy, they think? The man casually places his folder file on the desk, then launches into a story about a 'male, 45 , married, career as a criminal lawyer' whose behaviour was bizarrely effected by a brain tumour.

After the anecdote, the Professor throws a series of questions to the audience: 'Who believes in nurture?', 'Who believes in nature?', 'Who believes in God?' The questions are flung, fast and furious, and we do not get to see who is raising their hands. We hear laughter again. This man is crazy, yes, but he is also good fun.

'They' are showing us this YouTube clip as an example of a certain lectureship style. 'We' are staff at a university, jumping through the hoops to gain a teaching certificate.

We debate the man's style. Does he talk too fast? Is he too challenging? Does it look like the beginning of a Hollywood movie; Robin Williams at the front of the class shouting 'Carpe diem'? What will the students learn from this encounter? Will they remember anything he said or just the fact he is slightly off-beat, not the usual sedentary lecturer? Will the man become the lesson?

I consider the possibility of walking into a tutorial and acting this way. The image does not come. I am not an older man, I do not have the ... what is the word ...? Well, if I cannot even find the word, how can I stand with such authority, with such knowing, and entertain the masses; a lecture hall full of undergraduates who can sniff out the slightest whiff of fakery.

\section{Schopenhauer's moments (1)}

He strides into the Berlin lecture hall, leather briefcase in his hand. His suit is pristine, the white of his cravat and shirt immaculate, his shoes polished. $\mathrm{He}$ focuses on the lectern, a solid wooden pulpit on which to place his notes (although he does not really need them). His hands steady, his tongue moist, his skin dry. Knowledge is embedded in him. No distractions. No family. No wife with petty domestic problems. He breaths his epistemologies. He lives them.

He looks up, ready to begin. 
The hall is empty.

\section{The tutor (1)}

My hands are shaking, my lips dry. In the student union I cradle a bottle of just purchased Mount Franklin water, trying to let the fridge coolness chill out my sweating palms. I haven't bought a plastic bottle of water for years (like a good hipster, I use tap in BPA-free-enviro-bottles), but my daughter's Prep teacher has asked us to bring some in, for them to be used to make butterfly feeders.

I'm feeding my own butterflies. I'm half an hour away from the first tutorial of semester and the familiar nausea sits at the bottom of my stomach. I look at my class plan again: the carefully dictated minutes, every segment of time accounted for, the movement from one exercise to the next. An orchestrated flow of activity.

A flashback to last year's class. I had asked the students to bring in one of their favourite short stories. A young male student brought in a short, short story by Jorge Luis Borges, 'The Exactitude of Science', though he did not have the author's name on the piece. As I began to write up the other wellknown authors' names on the whiteboard - Ernest Hemingway, Raymond Carver, and Alice Munro - I suddenly knew I had no idea how to spell Borges first names. My heart began to pound and I could feel the blush of red rising across the top of my cheek-bones, the horribly obvious, clichéd signs I have always had when nervous or under stress.

The young male smirked as I stumbled with the spelling (horror of horrors, did I really write "Gorge"?) He had lost respect for me ever since I'd declared writing about 'flashing eyes' was bad writing. He'd countered that Dostoevsky had done it 'all the time' and my inability to conjure up the author of Labyrinths added to my spiralling inability to prove I had anything worthwhile to say to him, or to teach to him.

I sit wondering: had he done it deliberately? A test to see if I knew what he believed I should know? A little trap to show up my ignorance of what he believed were the litmus test papers of literary comprehension? Or is this my paranoia gone haywire?

\section{The imagined student (1)}

You sit in the plastic chair with your back slightly turned to her. You should move, shuffle around, but you can't be bothered. She is talking about point-ofview and you think it's kinda ironic to be showing her your shoulder while she pontificates about first, second and third person. That girl who seems to have a crush on you is sitting opposite and she gives you a small smile, like we're in this together. She doesn't wear shoes and you find the thought of her filthy black feet being anywhere near you quite disgusting. Still, the story she wrote about going to see an Indian guru wasn't as bad as some of the other stuff your class has brought in. You can't understand why She isn't more brutal. You don't understand how these so-called writers can be reading Jodi Picoult. You listen in for a moment.

The second person is probably the hardest point of view to employ, because it often has the effect of alienating the reader. To be constantly told "you" are doing something can be irritating. Although it does have the 
advantage of drawing attention to the difference between the character's interpretation and its reception.

You don't remember any of the Russians - Dostoevsky, Tolstoy, Pushkin - using second person and they were certainly never self-indulgent enough to use first person. All this 'I', 'I', 'I' everywhere. Your novel will definitely be in third person ... when you get around to starting it.

\section{The tutor (2)}

A permanent staff member tells me she gets diarrhoea before every first class, even after eight years of teaching. A fellow sessional tells me he stuffed up his own "ice-breaker" (the now standard device used in first classes where each student has to introduce themselves to the rest of the cohort). I recall my own first ever class where I got the room wrong, sprinted across campus, arrived ten minutes late, panting, and couldn't get the technology to work.

A fictionalised Janet Frame in Jane Campion's An Angel at My Table stands at the front of the classroom, with a piece of chalk in her hand. She turns it over in her fingers, examining its contours. She is unable to commence and the school children begin to fidget. The awkward sounds of bafflement. Why isn't she starting? When will she turn and become our teacher? And in the next scene she is running onto grass, having fled the classroom sobbing, her bright red hair bobbing up and down in her escape.

Every semester, I have visions of doing such a thing.

A copywriter tells me to 'fake it 'til you make it' and I think of the ability to re-write, to re-draft, to re-imagine. The safe, comfortable space behind a computer, tapping out your knowledge, googling the gaps. In the classroom, there is no rewind button and to admit to an internet search is as good as declaring yourself stupid.

\section{Schopenhauer's moments (2)}

He looks again. He knows he is on time. He knows his audience should already be gathered. Yes, there are other attractions in Berlin. Some will be lured away by the famous 'know-nothing' but, surely, not all?

Ah, here is a discerning philosophy student now, slinking in like a thieving cat. And another. And, yes, another. They have a slightly fugitive look to them, as if worried they are being watched, recorded or reported. A small part of him wishes this were true, that his work would have made enough of an impact to draw the attention of the authorities. He cannot fool himself, though. None of the three, no four, no five young men sitting scattered around this gaping hall, under a roof disappearing above them like the dome of St Paul's, will have read any of his words, let alone anyone higher up, anyone of importance.

He clears his throat. 
You can't think of a thing to say. The boy you thought was cute - in an intellectual/pretentious way - has just read out a very short story and you have no idea what it was about. Your head is pounding slightly, you've got that lowlevel headache you always get when you know you're supposed to be doing something and you can't quite figure out what it is. Everyone else in your group has said something. At least, you think so. Maybe the short, pudgy girl with glasses hasn't spoken either? Or maybe she did and you missed it, so focused on your own inadequacies?

You stare down at the words on the page again and wish you could reread it quietly to yourself. As the boy was reading it out, you could hear the other groups reading their stories - lines of metaphor and simile all crosstangled with one another - and this one lost all sense. You know it's not a piece that will ever make perfect sense anyway. Not to you. It is only one paragraph and requires background knowledge you don't have. He might have explained it already, but you've missed that as well. You continue to sit in your silence, gazing at the black marks on white paper. They were once such comfort. A world to retreat into when nothing else could offer solace. Now, you feel them becoming yet another space of confusion. The boy drones on about this Argentinian writer and you feel awash in his contempt, another face in a sea of confusion. He stands safe on land, so self-assured. You have the wild desire to reach out and grab him, as if merely touching him will infuse you with his knowing. You sit still, willing the time to pass more quickly.

\section{The tutor/mother (1)}

I finished my $\mathrm{PhD}$ in 2009. The next year, I had my first child and, two years later, another. Five years away from the academy had seeped me in epistemologies of a different kind. From postcolonial theory and narratology, I had moved into the American confusion of royalty and re-mapped my own mortgage-driven territory: I could sing you the theme tune of Disney's Sophia the First (try telling my daughter it makes no sense for a princess to be named "the first") and could locate every park within ten kilometres of my home. I could read Hairy McClairy from Donaldson's Dairy with my eyes closed (and I often did) and was a member of the local, not the university, library, for the first time in my life. I knew the familial relationships of a group of animated pigs whose antics were so mundane it was comforting. So much I had not known, so much I didn't need or want to know.

In the initial baby stage, I remember still being able to read, to find time to keep connected with the literature I believed scaffolded my life. But your children's presence seeps into you both brashly, with the screaming cries and the temper tantrums, and quietly, from conversations at breakfast to stories at bedtime, until you find your head no longer full of questions about narrative structure or the right voice for your latest piece of fiction, but how to answer the urgent plea of 'what should I do to make friends at school, mum?' or 'where are my fluffy bunny ears?' or 'why do caterpillars eat leaves'? I became an expert in knowledges I couldn't have imagined: in pop psychology ('ask them if they want to play with you, with a smile'); practical life-skills ('look under the couch') and the natural sciences ('because they have the right kind of stomach for it').

Coming back to the academy after this break - as a teacher now, not a student - was stepping back into a once-familiar world with different, aged eyes. Maybe Freud would have called it an encounter with the uncanny; it was as if I had returned to my birthplace but where everything seemed strange and 
slightly threatening. How could I ever have the same urgency about writing I once did? The passion and belief that literature was the be-all and end-all of existence? How could the words 'phenomenological hermeneutics' or 'dialogical paradigms' ever seem important again?

This is not to fetishize parenthood, to claim my world-view has inextricably changed since procreating or to place the birthing of children above intellectual pursuits. I simply know I will never be the same person who was able to completely and utterly dedicate myself to the writing process, that I will never have the same exclusive focus on my art. And to look at the persona I might have been able to project before the foregrounding of my domestic situation, to compare this different creature who must now stand in front of sixteen undergraduates, purporting to be a professional writer with wisdom and knowledge to impart.

\section{The imagined student (3)}

You cannot bring yourself to smile. She is grinning too much. It makes her face look weird, scrunched up and a bit out of kilter. You think about how you might put that line in your journal and your fingers twitch to get it out of your bag. But that'd make too much noise and the last thing you want is to draw attention to yourself. You sat at one of the back tables because she might be one of those ones who gets everyone to introduce themselves one-by-one and you certainly don't want to be the first to have to do it. In your other classes, this wasn't such a big deal. All you had to do was talk about what school you came from and what major you were doing. Here, it might get personal. You don't want to chat about the scribblings of your mind, even though you're also desperate to share them, to get some sense that what you've been doing is not a complete waste of time.

She's giving her biography and makes a joke about her books - 'not exactly best-sellers' - and there are polite chuckles around you. You still can't bring yourself to smile although you like the fact she's being self-depreciating. Her grin has settled down to a simple curve of the mouth. She has a bottle of Mount Franklin water in her hand and she keeps screwing the cap on and off. Every few sentences she takes a sip, though her mouth still looks dry. You wonder if she knows that Coke owns Mount Franklin and if she's aware of the mountains of landfill these corporations create. You suddenly wonder if she knows anything, if everything she is saying is not complete rubbish. For the whole of the two hours of class, you do not smile.

\section{The eye-patient (1)}

In the last three years, I have visited an optometrist three times and an ophthalmologist twice. In the course of a simple eye check-up, they had found a bump on the macular of my left eye and it has been the subject of scrutiny ever since. No visible changes in my eyesight, yet the tiny future threat of macular degeneration.

At both trips to the ophthalmologist, they placed drops in my eye to fix the pupil - all the better to see you with - so I was unable to focus my eye for two hours or so.

In the first instance, I went to a café with a friend and she had to read me the menu. In the second, I went home and listened to music. During the time it 
took for my vision to return to being able to discern fine detail, I hungered for clear, crisp words. I wanted the clarity of written language, the voices tethered to the page ten, twenty, a hundred years ago, to speak to me again. To no longer be alone inside my head.

In those moments, I realised how words on a page still hold me to life, how my love for them hasn't disappeared since having children, only that the form of my love had evolved from one state to another (yes, it's too cheesy to bring in a reference to caterpillars and butterflies here but you can detect it, humming underneath).

\section{Schopenhauer's moments (3)}

He clears his throat and feels the five young men become still. Not as if they were fidgeting before, only they have assumed their listening positions, empty vessels ready to be poured into. What does it matter if the quantity is not large? Haven't revolutions been started by just a handful? He straightens his immaculate notes (not that he needs them) and begins.

When at times I felt unhappy, this was by virtue of a misunderstanding, of a flaw in my person.

But this, he thinks, is not how his lecture begins. And yet, here he is, speaking the words.

I then took myself to be other than I was and then lamented that other person's misery and distress, e.g. for a Privatdozent who does not become a professor and has no one to hear his lectures; or for the one of whom the philistines speak ill and the gossips spread stories; or for the defendant in an assault case; or for the lover who will not be heard by the girl with whom he is infatuated; or for the patient who is kept at home by illness; or to be other similar people who are affected by like miseries. I have not been any of these. All of this is strange cloth from which at most the coat had been made that I wore for a while and that I then discarded in exchange for another.

Where are these confessions coming from and why do not the five men stamp their feet in agitation at an aspiring academic speaking the secrets of his heart?

\section{But then who am I? [1]}

He looks up and sees the five men are not young, as he thought. They are actually old and wear familiar faces: Locke, Kante, Fichte, Schelling and, of course, Hegel. None of them are smiling. He is tempted to ask Hegel what he is doing here - doesn't he have his own lecture to be giving? - but the tenacity of his youth seems to have evaporated in this stifling atmosphere, under the heavy weight of so many competing philosophers/ies.

\section{But then who am I?}

He repeats the question and the faces remain blank. For a moment, he considers the possibility that he is no one and that his work has fallen into obscurity, his ideas have been lost or, worse, derided and dismissed. For a moment, he is not calm, he is no longer confident of his contribution, of his solutions. If there is a hell, this is his. 


\section{The child (1)}

At twelve years old I decided I wanted to be a Guide Dog trainer. I walked around the house with my eyes closed, feeling the textures of the walls, the edge of the couch, bumping my toes into the ridges of the stairs. I tried desperately not to cheat, not to let a small slither of light creep into my pretendblind eyes. Inevitably, I would encounter something I didn't recognise by touch or smell or taste - something cold or slimy - and I would have to break the illusion.

My mother didn't put the kybosh on my aspirations, even if she might have secretly wondered if it was a long-term sustainable career. She failed to point out to me my less-than-enthusiastic relationship to animals or my famous tendency toward impatience. She let me stumble, realising gradually I didn't have the temperament for a job requiring repetition and tolerance of less-thancogent (furry) beings.

I needed difference. The precariousness of imagination and perception. The who-knows-what-will-happen-next of artistic interface. The breath-taking ridiculousness of creating something from nothing, every day, and pretending you know what you are doing and how it is done.

\section{The eye-patient (2)}

Schopenhauer in The World as Will and Idea:

The process by which children, and persons born blind who have been operated upon, learn to see, the single vision of the double sensation of two eyes, the double vision and double touch which occur when the organs of sense have been displaced from their usual position, the upright appearance of objects while the picture on the retina is upside down, the attributing of colour to the outward objects, whereas it is merely an inner function, a division through polarisation, of the activity of the eye, and lastly the stereoscope, - all these are sure and incontrovertible evidence that perception is not merely of the senses, but intellectual - that is, pure knowledge through the understanding of the cause from the effect, and that, consequently, it presupposes the law of causality, in a knowledge of which all perception - that is to say all experience, by virtue of its primary and only possibility, depends. [2]

\section{The imagined tutorial (1)}

I walk in with the mantle of expertise on my shoulders.

You are trying not to smile at the t-shirt she's wearing. It reads 'Young, Wild \& Free' inside a circle topped with Indian arrowheads. It should read 'Old, Tame \& Tethered' and shouldn't be using Native American symbols.

I walk in, wondering if any of them will notice I'm wearing the same pants as I wore to the lecture and hoping they'll see my t-shirt as ironic. 
You are hanging out for her to say it's time for a break, rolled and ready. You hate it when she forgets. Like she's never had an addiction. Like she's some kind of learning freak.

I walk in, trying to guess how many of them will have done the readings, how many of them will have embraced this week's writing extracts, how many of them will actually speak?

You can't believe she's got your name wrong, again. This time, you don't even bother to correct her. What does it matter? When she realises her mistake, she'll blush and you can stay something witty and scathing like identity is fluid and show her, yet again, how much cleverer you are than her.

I walk in, thinking about how the lines on the Excel sheet I use for the roll have started to look wavy again and whether I should book yet another expensive ophthalmology appointment where they will tell me to 'keep an eye on it' without any sense of irony.

You hope she's going to talk about the readings this week because you've just finished them on the tram-ride and they're amazingly fresh in your mind. You hope she's going to ask a question you can answer so you can make up for last week's stultifying silence, so you can share these ideas swimming in your head. You hope you can finally let yourself smile.

\section{Schopenhauer's moments (4)}

But then who am I?

The man who has ... provided a solution to the great problem of existence that perhaps will render obsolete all previous solutions, but which in any case will engage thinkers in the centuries to come.

I am that man, and what could disturb him in the few years in which he has still to draw breath?

He blinks and pulls at the knot in his cravat. The old men have dissolved, faded into nothingness, and, in their place, the young men sit once again, eager and interested in what he has to say.

He presses his lips together and speaks.

\section{The tutor (3)}

When Arthur Schopenhauer strode into that Berlin lecture hall in 1820 was he as sure as I have imagined him? Did he not have any misgivings about scheduling his lecture at the same time as Hegel? Was he so confirmed in his knowledge, that there were no nerves, no flutterings and no worries (mate)? Did the shadow of doubt lingering in his secret diary ever come to the surface? Was the confidence of these great thinkers ever so shaky? Will there come a time when I will be assured and without doubt? When I will strut into the tutorial room with the swagger of that Professor of Biology?

Or will I continue to ask: who am I and what do I know? 
I am half-way through the semester now and know, with certainty, I will never stand on the table and cry 'O Captain! My Captain!' in a booming Walt Whitman voice. But nor will I sprint out of the classroom and fall in despair, weeping, onto my hands into the wet grass. I will play the middle ground.

I know I will endeavour to impart tiny droplets of wisdom, sucked from the well of my experience, as tutor, as mother, as eye-patient, as child and as writer. I know I will make no reference to Dostoevsky or any of the Russians. I know I will guide, but not train. I know I will say 'I don't know' when I don't know. I know I will watch my student's faces and try to perceive them less negatively, focusing on the moments when they are generous and respectful and willing to listen.

I walk in.

\section{Notes}

[1] David E Cartwright, Schopenhauer: A Biography, 2010, Cambridge University Press, Cambridge. return to text [2] Arthur Schopenhauer, The World as Will and Idea, 1907-1909, translated from the German by RB Haldane and J Kemp, Kegan Paul, Trench, Trübner \& Co, London. return to text

Dr Rachel Hennessy's second novel The Heaven I Swallowed was completed as part of her $\mathrm{PhD}$ at the University of Adelaide. It was Runner up in The Australian/Vogel Award and longlisted for the Nita B Kibble Award. She teaches Creative Writing at the University of Melbourne.

\section{TEXT}

Vol 20 No 2 October 2016

http://www.textjournal.com.au

General Editor: Nigel Krauth. Editors: Kevin Brophy \& Enza Gandolfo

Creative works editor: Anthony Lawrence

text@textjournal.com.au 


\section{TEXT prose}

\section{Lynn Davidson}

\section{A roof over my head}

On a single day in a wintery week I finished reading Charlotte Wood's blazing novel The Natural Way of Things and went to the Degas exhibition at the National Gallery of Victoria. I went to the exhibition in the early afternoon instead of applying for a job - or another in the patchwork of jobs that keep a roof over my head. I needed my brain to be washed through with colour and dance and process. I wanted to remember about movement and change; things even more reliable than death and taxes. Later that day, on a $1 \frac{1}{2}$-hour train journey from work, hungry for dinner, I finished Wood's novel. I read how the main character, Verla, makes a hard and conscious decision to 'jump off the bus' that is taking a group of brutalized girls 'home' to the implied safety of a corporate, market-led world.

I teach creative writing, and now that tertiary teaching has been largely casualised, my working life is mixed: rich, stressful, and very often and very suddenly just not there. There is no continuity. So, four evenings a week I travel three hours to tutor kids for two hours at a modest hourly rate. This saves me from financial free-fall when the university semester ends (well, not quite, this job is also 'casual' but the holidays are shorter and the work more reliable). I give you this context because both the book and the exhibition are about work, about women's work. So here's another bit of context. I was a single mother who raised two children without financial support from their fathers. Any reserves of energy and time were spent on a very long battle around custody of my daughter. But those difficulties aren't the defining things. Our little family had, and has, a good time. It's just that I'm writing about women's work and art, and suddenly this fact of single parenting seems important to say.

Christos Tsiolkas describes The Natural Way of Things as 'a howl of despair and fury' and that, 'As allegory, as a novel, as vision and as art it is stunning.' It is about a group of young women who are taken to a compound in the middle of the Australian desert because, it seems, they have been outspoken, and broken some rules of patriarchy. They are made to wear long dresses and bonnets and their heads are shaved. It is a novel about misogyny, corporate power and survival. Wood reveals something often inexpressible in daily terms, about us - we humans - our trappedness in roles and consolations for those roles. She reveals something often inexpressible about those who think they are the makers, and those who suspect that they are the 'made'. Wood writes, 'The mercury spreads through her, icy, unstoppable. She was an empty space to be occupied. When she was gone he would find another.' (Reading this on the train, on the long journey from work, I felt my chest constrict. I wanted to get off.) I could in some way recognise and relate to Yolanda, a character who, in despair and in refusal, redirects her process of becoming towards the earthy life of rabbits. Who has not at times wanted to become a rabbit? (On the train a toddler sitting on her mum's lap reaches across the seat to stroke the arm of my jacket. I smile and say 'it's soft isn't it'. She 
then gets me to stroke the grey fur of her toy koala and we agree that that is also soft. Then she strokes my jacket again, and lifts up her koala so we can both stroke it and agree on its softness. We do this five or six times.) Who hasn't at some point wanted to become a simple, earthy creature: colour and movement on a wide wild plain.

Much of the art included in the Degas exhibition shows women at work: laundry workers with strong shoulders and forearms and the steam of hissing irons, brothel workers waiting for clients to turn up, and dancers inspecting the sole of a foot, adjusting a strap across a strong shoulder. There were muscled calves descending a delicate spiral staircase. There was the work of preparation: long swathes of hair held in one fist. There was a lot of balancing on one leg. The sculptures were often of women washing themselves: an armpit, a long sweep down a torso, their long, long hair. We saw them twist around to do this cleaning of self, and how that made certain folds in stomach or side. The women seemed to be emerging from bronze, as though making themselves. Birthing themselves. Wiping themselves clean to achieve their form. Dragging their hair free. And as I looked at the paintings and the sculptures, I saw that Degas understood something about female oppression. Something about contracts and power and survival. It's an intelligently curated exhibition. The famous painting Finishing the Arabesque, which is so beautiful, has a note explaining how the dancers who weren't the principal dancer often had to supplement their income by providing sexual services for men who had come to watch the ballet. It gives you pause for thought. It draws you to the background of the painting where the rest of the dancers gather. It makes you wonder about the principal dancer, so graceful and pretty in her white flowerlike dress. In the exhibition, through all of the washing, all of the work, all of the drudgery, is grace. Some misogynist painters aligned with Degas thinking, mistakenly, that because he did not idealise women in his paintings, that he hated them like they did. His famous bronze of the young ballerina, the one he strangely and wonderfully 'dressed' in a shabby tutu and thick satin ribbon in her hair, was criticised for being 'the ugliest of the ugly'. It isn't ugly. She isn't ugly. She was a fourteen-year-old dancer. She was a girl standing confidently. In this alone, she is beautiful. Her mother was a prostitute, and at some point this young dancer disappeared back into the place that is called the underworld. Who can know for sure what Degas thought of women? But I see these hardworking women as strong and in some way self-realising. Self-making.

In her acceptance speech for the Stella Prize, Wood said that when she was having a hard day, wondering why she was 'writing a dark, bleak book about girls imprisoned and trapped and reviled'she wrote herself a series of reasons to keep going, and this is one of them: 'To make, at all. To create is to defy emptiness. It is generous, it affirms. To make is to add to the world, not subtract from it. It enlarges, does not diminish.' And this is another: 'Because as Iris Murdoch said, paying attention is a moral act. To write truthfully is to honour the luck and the intricate detail of being alive.'To finish reading The Natural Way of Things on the same day as going to the Degas exhibition is to hear a vital conversation across centuries about art and women and power and unmaking and making. The conversation is at least as vital now as it was then.

I got my undergraduate degree slowly, before, during and after having my kids. It spanned the period when I was with my son's father (my husband) and then my daughter's father, and the beginning of the long period when I was on my own. Student fees were low in those days; a degree was affordable. My last two papers were taken extramurally and I sat my final undergraduate exam when my daughter was a fairly new baby. My mum waited with Tamara outside the lecture theatre while I sat the exam so I could feed her just before and straight after the exam. A few years later, I managed to complete my MA in 
English Literature just before Work and Income New Zealand cut subsidies for university study for people on the Domestic Purposes Benefit. My parents brought Elliot and Tamara to the graduation ceremony. Tamara fell asleep on the floor at their feet, but Elliot stayed awake and upright, proudly wearing a suit he'd borrowed off his mate. I felt that study was helping me towards finding work that mattered to me; it kept a light on that illuminated the future. It also kept me in touch with the conversation about literature and, if I couldn't afford to meet friends in town for a movie, I could meet up with the wonderful Seamus Heaney any time I liked (my MA looked at Heaney's 'Station Island' poems). Doing this study gave me structure. It kept me hopeful and helped to stave off depression. If I couldn't write much because it was hard to bring a struggling and fractured and tired self to the empty page, I could study. The poetry books, the deadlines, the necessity to get into the city most weeks and the trips to the library, without question, kept me sane. It is a particular and deep circle of hell to be raising children on next to no money, while defending yourself as a good mother to lawyers in the Family Court. I would drive myself to meetings with my lawyer and to hearings. I would drive myself home. After picking up the pieces, there would still be my funny and interesting children, and there would be my study, my words, my books, the library, seminars, tutorials. The Family Courts stuff went on for all of my daughter's young years, starting when she was just under two years old and finishing when she turned 16 , when she could make up her own mind, and chose to shift into to one home, with me. She was no longer dragged confusingly between houses on a roster that I, let alone her friends, struggled to keep up with. A roster that had a lot to do with ensuring her father could continue to work without too much impediment.

When people ask if libraries are important and relevant these days I want to scrape my fingernails down my face. Are you kidding! As the days get darker (and they are getting darker), libraries give us context; they contain our past, our present, our future, and the way we are different and the same. They are also warm places for cold people. There are free books for anyone who wants them, and free WiFi so you can do a job application if you need to. You can do your homework in a library if it's too noisy at home. They are a safe place and they contain some of the wisdoms of the world.

I have taught creative writing to people from all walks of life, which I find to be the same walk, pretty much. I have taught and learned so much from older women at a WEA writing class at the Otaki Women's Centre. I taught on the Whitireia Writing Programme for many years, first of all in Porirua (oh the riches of being there) and then on Lambton Quay in Wellington. While at Whitireia I wrote and delivered a year-long poetry course to a brilliant group of writers - this was the same year that I did an MA in Creative Writing at IIML. I felt like a gatherer of treasures that year, gathering from my extraordinary class at Whitireia, and gathering from my classmates at IIML; buckets of interesting, enriching stuff passing between hands as I moved between student and teacher, between Kelburn and Lambton Quay. I have taught people of all ages and backgrounds, of varying and surprising talent. I have learned there is no way to predict who will be the really interesting writer - degrees or confidence or verbal eloquence are no indicator, neither is having been in prison, or having a mental health problem, or being poor or marginalised. I tutored fiction and poetry at the stately and beautiful Melbourne University, holding tutorials in the Ian Potter Art Gallery on campus; tutorials where students didn't want to leave at the end of the session because the conversation about a comma in a poem, and the surprise when you took it out, was just too interesting to shut down. These lovely, financially privileged, ordinarily confused young people laughed out loud, and often, at how far they had fallen into the poems; fallen into the language. Melbourne University, in a recent School of Culture and 
Communication Sessional Lecturer and Tutor Selection Review, have made a ruling that: "no sessional coordinator or tutor should continue either tutoring or sessionally coordinating a subject for more than 3 years without significant review or reason (e.g. lack of another appropriately qualified applicant).' My hunch is that this safeguards the university against having to offer a tutor or coordinator a permanent position because they have taught the same course over several years. The ruling will lead to the loss of some experienced and well-qualified tutors and course coordinators. One wonders who the less experienced tutors will turn to for support and advice? I wonder how we tutors will continue to keep a roof over our heads. I wonder what the students who pay ever-increasing fees at this prestigious university will think about tutors who perhaps don't have the skills and experience required to do the job.

Last year I completed my $\mathrm{PhD}$ in Creative Writing. I have a debt now, and still only fragmentary, casual work. I am not alone in this. I have to hold on to the value of the work I did for my thesis. I think I took part in the big conversation. I have to keep reminding myself that the work is valuable, even if it's not particularly valued in the corporate, commercial world. I'll keep on with it, the writing and the research, because it's what I do - taking heart and inspiration from art and words, most particularly at the moment from Degas' fourteen-year-old dancer who had the damn gall to look confident and undiminished. But the old structures that helped me stay sane through personally difficult years, those old structures in their freshly elite forms, seem to be coming apart. With increasing pressure to fit the market model, universities are damaging what matters: equality of opportunity, creativity and an invested, committed workforce. I want to write something now about how we are makers, and that when those big structures are no longer fit for purpose, we will make smaller more human-scale ones. But for now that would feel overblown. Let's just keep the lights on in the library. If the lights are on in the library, we could gather there when our universities are finally and irreversibly reduced by the market-led stakes to which they are tethered.

Lynn Davidson writes fiction, essaysand poetry - most recently Common Land, a collection of poetry and essays. Her work has appeared in journals and anthologies including Sport, Australian Poetry Journal, Cordite, PN Review, Best of Best New Zealand Poems, Essential New Zealand Poems and Another English: Anglophone Poems from Around the World. In 2013 she had a writing fellowship at Hawthorden Castle in Scotland. Lynn teaches creative writing and recently completed a PhD in Creative Writing through Massey University, Wellington.

\section{TEXT}

Vol 20 No 2 October 2016

http://www.textjournal.com.au

General Editor: Nigel Krauth. Editors: Kevin Brophy \& Enza Gandolfo

Creative works editor: Anthony Lawrence

text@textjournal.com.au 


\section{TEXT prose}

\section{Toni Roberts}

\section{Making with mud and my mother}

\section{Part 1}

It is Mothers' day, 2015. My daughters bring me blueberry pancakes and a nice cup of tea in bed. It is a perfect treat, but brief. They have other things to do, so I'm left to myself. I head out to the shed. My slip cast bottles need fettling and sanding in preparation for bisque firing. It is meditative work, incidental daydreaming, remembering and imagining time, while hands move and objects are finessed. There's a lot of hand-ling, allowing mind-ing to wander from this moment and this shed to other moments, and another shed further back...

I had a childhood of making. My mother loved all kinds of craft; starting with knitting and sewing as a child, she then made clothes for all of us kids and even for our toys (my Barbie had some very groovy ' 60 s gear and Ken had a smart suit and tiny black vinyl shoes). She later took up spinning, weaving, leatherwork, batik, and stained glass. When I, the youngest of five, started kindergarten my mother found clay, and it changed her life.

I grew up with clay and all the activities that led from a damp lump of earth to a functional or fantastical form. Stages are marked by the excitement of firing and the nervous anticipation of its outcome. I remember a late-night salt firing like some might remember cracker night or a solstice bonfire. The scene is dark, and faces blurry, but the sensations are vivid. The whooshing noise and flames of the gas burners set into a tall brick kiln that Mum had built in the back yard ... wrapping rock salt in newspaper and setting the little packets on a steel rod with a cradle on the end. The rods were inserted through a hole in the kiln, where they vaporised in a glow of orange. It was thrilling. Fellow potters from the art school were wrapped in warm winter layers against the Canberra chill, drinking mulled wine and chatting excitedly. This kind of event was foreign in our family - evenings were spent watching Bellbird and eating lamb chops and $3 \mathrm{veg}$, then more television until bedtime. But this was social, active and late. Something was being formed behind the brickwork, something magical, elemental, primal. The event glows in my memory like the vaporizing salt; bright against the dullness of ordinary life. Something significant was happening outside the kiln too, and I knew my mum was somehow central to it all, even though she was not loud or the life of the party. People like her friend Anita could be heard above the rest, laughing and chatting, but Mum was quietly there and I knew she was happy. The next morning we removed bricks to reveal the wonderful blushes of colour and orange-peel texture on her pots. Each one was a discovery.

...now I'm trimming the part line on a fine porcelain bottle. I scrape the fine knife through the hard clay, cradling the pot firmly but lightly, in case it crumbles in my hands... 
Mum and her friend Ruth had built two kilns in our backyard, even though her wrists had already been damaged by kiln building at the art school. They were twin kilns, vertical brick vessels with a space for gas burners or wood fire below, a tall chimney at the back and an arched doorway in front, which was filled in once the kiln was stacked with pots. I remember the arches being built - the magical moment when the last brick was inserted and the plywood formwork removed and, in defiance of gravity, the arch remained, suspended in mid-air.

For a while, my job after school was to clean bricks with a cold chisel and hammer. I don't remember where the bricks came from, but Mum was not one for buying anything new. So I would sit on the concrete and chip away at grubby chunks of mortar until they fell away from the brick to reveal a flat plane of dark red Canberra brick. These were stacked in a herringbone pattern behind the shed, awaiting kiln construction.

...I pour thick, creamy slip into plaster moulds to cast some new bottles so they can be taking shape while I work on the dry ones. Although there is no urgency of production, I take satisfaction in simultaneous progress...

I remember her in the shed in production potting mode, making bowl after bowl (clay weighed and measured for consistent size), cup after cup, making lids for casserole dishes that fit snugly in their seated rim. I can picture the glazes and finishes at different periods in her potting career: tea dust teapots, Shiga red jugs, her signature swirled slip dip, stenciled silhouettes and '70s browns, and the pots she made for the theatre shows I did - Under Milkwood mugs and Windows in Walls casseroles as gifts for the directors. Everything was a subject for making. Her work was mostly functional, meticulously finished and lovely to use. But she also made also odd, useless or decorative pieces, always experimenting with new techniques. I remember a giant purple hair curler - the old-fashioned type - with rows of tiny holes and spikes, and a ball seated in the end fastened with black elastic. Her miniature roll-top desk, complete with wood grain texture, drawers and tiny shelves, still sits in my parents' dining room, atop the original desk it was based on, exaggerating its scale.

...the slip has set in the moulds so I carefully prise apart plaster to reveal the watery swirls of blue and white clay that have formed a new pot. I still get a little rush as each unique pattern is revealed. I trim the base lightly but it is still so soft - I will work on this one more tomorrow...

I remember making things with my brother when I was about 6 and he 12. I was sitting on the same grey-brown stool that now lives in my shed. We sat at the cloth-covered bench next to her old enamel potbelly stove. We were sculpting little animals, making woolly sheep from clay pressed through a sieve, and snakes coiled for attack, baring their tiny sharp fangs. Mum admired his ability to bring character to each creature, giving them quirky expressions.

I remember her 'pulling' handles - a technique where you hold the clay in one hand and draw it out with the other, dipping your hand in water and then stretching again, gently and evenly until the handle is the right length and thickness for a mug or jug. My childhood was filled with these verbs of making: often pedestrian words given special meanings:

pulling

turning chattering

firing wedging 
roll, throw, slice, slide, cover, dry, trim, fettle, sand, fire, dip, glaze, fire, grind...

Even the nouns implied action, like the coiled energy held captive within an atom:

slip

wheel

mould

flux

kiln...

Some words came from the special language of potters, drawing from a global heritage of mud makers:

saggar

oxide

raku

bizen

shino

teadust

majolica

sgrafitto...

I remember. Making is remembering, re-knowing, being with my mother, through the mud, a swampy, viscous connection. I feel our symbiosis, even now in her absence.

Making is a kind of mothering, giving life to creatures that soon become independent in the world. Her winged pots were heavy, hand-built shapes with arms outstretched - these became one of her signature forms: majestic, earthy strong. My porcelain bottles are people too - some with broad shoulders, some squat, with a full belly, others a little kinked and crumpled. I like them to feel worn, softened by life but not weighed down or broken by it. Character-ful vessels.

Yet making is also in tension with motherhood: the conflicts of time and focus; the different ways of thinking and being. Even though my mother shaped her creative life around us, I suspect she sometimes forgot about me when she was potting, which was probably a relief after so many years of mothering, constantly thinking of others. I don't like to leave my girls even when they are asleep, but going to the shed is not too far; I still feel close, tethered. I can squeeze some shed time in between: while the dinner is cooking; before I have to pick them up or drop them off; when they are studying. Making is both an act of self-realisation, and the most indulgent of activities. It requires certain preconditions: satisfaction of basic needs such as food and shelter and healthy children, feeling that I'm doing a good job as a mother. Charny (2011) describes making as a way of exercising free will. For a mother this freedom may come in small packages. It is sometimes only a virtual state of dreaming and scheming about making.

There is little time for reflection in a life focused on motherhood and earning a living. Emotional and mental energy is focused outward, bound up in children and their activities. Shed time daydreaming makes space in this production cycle, drawing my mind inwards whilst my hand reaches out and shapes a worldly form. Writing about dreaming demands even more space, to reflect and capture and interpret. I can't make and dream and write it - writing is always before or after the fact. Making always feels more urgent. 
...I sand the bases of my dry pots on a grinding stone to make sure they will sit upright on smooth bottoms and not slouch or wobble...

My family was built on incidental conversation, intimacy created by shared making, recycling, repurposing. At my Nan's house we'd sit at the table for tea and cake and she'd hand me a pair of big heavy scissors and some holey old panty hose or a moth-eaten jumper. We'd chop and snip, reducing the garment to spongy, chunky filler for cushions that Nan would make and sell at her op shop. At 50c each they didn't make the shop's charity rich, but we were making something from nothing, forming objects from waste. The redundant became useful, purposeful, beautiful.

Mum worked with great economy of materials: reused, recycled clay, trimmed swarf reconstituted and wedged back to life. Mum loved that nothing was wasted in pottery - trimmed remnants could be thrown into a bucket of slops then spread on plaster batts to firm up for wedging and re-use. Wedging hours of wrist-ruining wedging of the firm mud and wet slurry until the two combined into a smooth, even dough for throwing. She could have avoided the wrist damage by using a pug mill to prepare the clay, but Mum persisted with manual methods. Perhaps she felt guilty that this vocation of hers didn't make much money or perhaps she felt undeserving of mechanical aid. But this frugality did not extend to economising on making. There was no thrift on quantity of product, but a plethora of outputs across crafts and forms to serve so many daily needs: warmth, comfort, eating and drinking. But no need was so great as my mother's need to make.

My mother called herself 'craft-y', not in the secretive, conniving sense, but in the craft-ful, ingenious, make-something-from-nothing kind of way. She was too full of guile for the former; too naive and open-hearted.

After I left home I didn't keep up with pottery but I was still a maker, in amongst all the other -ers that I've been: teacher, mother, writer, designer, partner (for a time). I steered clear of pottery because, even though it was the love of my mother's life, it also spoke to me of being captive, chained to the daily demands of pots that needed attention, like small, hungry children: making sure they don't dry too fast; trimming and turning the bases; fettling and grinding. My memories of the many stages and hours of work that went into each pot and the numerous points at which disaster could strike; all these seemed too weighty, too emotionally demanding to be my creative escape from domestic life. So I taught myself to work in resin: that light-filled, glowing, clear mud, plastic fluid that sets instantly. I made resin windows, pictures, tables, platters, jewellery. I embedded stones and jelly babies, fabric, pot scourers and buttons. I made floors, donning protective gas mask, goggles and overalls, mixing huge buckets of toxic and costly liquid to pour and splash around the bathroom floor like some kind of Pro Hart madwoman. I loved it. It was my thing for a while. The knowledge I gained was my distinction from being swallowed up by motherhood and paid work. I had a dreaming thing, one that I could pick up and put down at will. Not much planning was needed, no daily tending. Pour, set, forget, then release, sand/polish, drill. No hurry. Its toxicity meant I couldn't share the resin work with my kids in the same way that Mum had with clay, but we did some projects together; they weren't excluded from the creative process but mud was not the medium of my parenting.

For one who spent so much time cleaning up after others, my mother seemed to revel in the messiness of pottery. She felt most comfortable in her clay splattered 'studio clothes'. 'You don't make anything if you don't make a mess'; mud and muck were welcomed. Her motto is particularly pertinent now 
as my backyard is covered in splashed plaster from recent mould making, the dog still traipsing white footprints through the house a week later.

As someone who had not studied for over 20 years, Mum must have loved the learning at art school. She must have been so bored as a parent, often home alone doing repetitive tasks without much stimulation. Little jars that once held domestic condiments like jam and peanut butter had a new life in her shed filled with mysterious minerals with coded labels: $\mathrm{CuO}, \mathrm{Mn}, \mathrm{Fe}, \mathrm{Mg} . .$. She embraced the science of glazes and constantly experimented with new recipes.

Our family was a small world when I was growing up. I now know that it hadn't always been that way; my older siblings remember holidaying with cousins and our parents hosting dinner parties. But that was a different decade; it had all dried up by the time I came along, evident only in the tiny holes in our patchwork linoleum kitchen floor that Mum said were made by stiletto heels. I struggled to imagine our kitchen filled with frocked women holding fancy glasses and suited men, chatting about ... what?? She told me that she stopped having parties because Dad would absent himself from the fashionable fifties frivolity and go to bed without apologies. Mum was humiliated by his absence and lacked the confidence to carry on as a solo hostess. The only social events I remember my parents having were occasional (and very sedate) dinners with relatives or one other family.

Married at 19, my mother was trusting and naive. Her father had been adoring and generous. My father was a tall, handsome and very successful tennis player; graceful on the court. But life is more than tennis. She had her first child at 22, then 3 more, evenly spaced 2 years apart. Then, 6 years later, in 1964, I came along. One of my sisters was born with severe brain damage and was eventually sent away to a home. She's 60 now, and still shows no recognition of any of us. For my devoted mother that would have been heartbreaking. Her sadness became a heavy fog of need that I recoiled from. I think she depended on my Nan a lot for support. When Nan died, my mother's sleeplessness, loneliness and drinking took hold.

'You will never be lonely if you are a maker', she said. That's not entirely true. Perhaps the making was borne from her loneliness, but the busyness of making also may have prevented her from seeking the company and support of others. That's a familiar tension; one that I have not yet resolved.

\section{Part 2}

For my mother, there was never a question of 'why make?' It was considered a primal drive, a given. But I do question this desire to produce. There can be no rational justification for creating more 'stuff' in this overcrowded, oversaturated world of products. Do I seek to improve on existing products? Do I aim to provide a unique experience for the end user? Often, I make things to free myself from the persistent visions, the insistence of ideas and designs that prey upon my daydreams, filling them with plans and possibilities. But this making is not without meaning. It doesn't sit completely apart from a designer's problem solving or desire to effect social change. The problems and challenges are small and multiple. The product of making is not a single, perfect item but a body of work, an array of attempts and iterations of objects that simultaneously perform and communicate. A teapot that is well balanced in the hand, that pours well (no mean feat) and strains without clogging. A teapot that sits well with its family of mugs - larger and shaped according to its 
function, but clearly the head of the family, not a ring-in from elsewhere. A teapot that refers to its heritage in culture and form, but is evidence of a unique application of hand and mind; one that generates a new presence. Making is the constant effort to reach from the given to the possible (Tin 2013). 'Making ... pursues a goal that is sufficiently clear to be perceived, but sufficiently unclear still to deserve to be pursued in and through the making' (3).

In my family, making is considered meaningful, productive work in a way that nothing else can ever be. This makes it hard for me to spend time reading. It is seemingly non-productive time. Being productive implies producing something that stands alone beyond the time of making; something that lasts.

Making is also a way of interacting with the world: pots are our representatives in social relations, extending beyond the small scope of our immediate social world. As makers we are not seeking immortality, but perhaps desire concrete evidence of our existence, and a proxy body in social connections. Making gives me a role; it makes me bigger. My objects are my distributed self, creating a network of relationships in the world while I stay in the shed. In this sense, pots are eloquent objects (Haraway 2004), characters that speak of the maker but also have their own voice. A work contains traces of its material origins, its physical transformations and the multiple relationships with its maker's body, skill and judgement, and communicates these both to its audience and back to its maker (Piper 2013: 5). The object represents both visible material form and invisible, immaterial forces (Ambrose 2009: 112).

Materials speak to makers of their potentiality. Although our grammatical categories oblige us to think actively or passively, the making process is both active and passive (Carter 2004: 14). Tin gives agency to the material as well as the hand: 'the bronze waits, inert ... it becomes a fastidious yet capricious friend' (Tin 2013: 2). This appreciation of the latent possibility of materials and the conversations they promise can lead a multi-disciplinary maker like my mother to collecting and hoarding, as nothing is rubbish until it has served all its possible purposes, lived as many lives as can be conjured for it or that it can insinuate. My mother's house was testament to her appreciation of the potential agency of materials.

Materials have character, both in the modes they afford a maker to interact with them and in their capacity for transformation. My mother was a voracious explorer of materials, investigating their qualities and potential, but clay was the most plastic of all, the one that yielded unlimited opportunities. Clay, slip and glazes are materials rich with potential for transmutation, a wonderland of experimentation and discovery. In my making I seek to retain traces of these material transformations: swirled clay is evidence of its liquid origins; the surface of a glaze also retains a sense of its fluid form.

Making with mud connects us with the base elements of our physical environment, as Piper describes in reference to glass (Piper 2013), and demands of the maker an openness to the effects of elemental forces. Each stage of making provides opportunities for unintended events and equally, for happy accidents and serendipitous effects, especially when the maker is open to the combination of science, chance and discovery. This requires a character that doesn't need to dominate or control everything, one that can enjoy the element of chance, one that can learn from failure and accept unintended outcomes. The Greek word kairos refers to the right moment or the opportune, and to serendipity. Kairo implies that there can never be more than a contingent and provisional management of the present opportunity' (White, cited in Carter 
2004: 14). My mother would have liked kairo. The jugs, vases and canisters that fused together when a shelf broke in the bottom of the kiln now form a centerpiece at my brother's outdoor table. It is an accidental sculpture of carefully crafted functional objects, disfigured by compression, fused and unified by the vaporized salt turning to a solid, lustrous glaze. There were no tantrums of disappointment, no fury that the maker's will was challenged. It is a sculpture that speaks of its maker's relationship with the elements.

The maker moves between mind-ful, directed making and a more distributed, bodily intelligence like that of an octopus. Sometimes the work is conceived in the mind and formed by the hand; at other times the hands work with their own intelligence and draw the mind with them; electrical charges shoot back and forth between hand and mind, intellect, emotion and senses, body, place perception and proposition. Similarly, in writing, sometimes a sentence is conceived in the mind and dictated by the hand; at other times, the words are transformed as the hand offers new intelligence and persuasive offerings. Sometimes the hand takes charge and exerts its own direction. Vaughan proposes that 'the localized acts of making and creating are the realizing acts of invention, the materializing of thought...' (Vaughan 2007). But making is more than the materialization of thought. It is the creation of thought, the activation and generation of knowledge through a physical, material process, a dialogue between hand, mind and material, and also with place, time and, sometimes, with other makers.

The maker can become so absorbed in this material dialogue that it's like a focused hypnosis. Csikszentmihalyi proposes that intense enjoyment arises from a challenging activity that requires skill, the merging of action and awareness, clear goals and feedback, concentration on the task at hand, a sense of exercising control, the loss of self-consciousness and the transformation of time (Csikszentmihalyi 1990). Under certain conditions, such elements can combine to create a sense of 'flow' in an individual. My mother found flow in mud.

Material thinking. Makerly thinking. Mud thinking. Mud making. Mud flow. Mud in the blood.

\section{Part 3}

At 68, without warning, my mum went into a coma. She remained unconscious for 4 days. When she woke up she had to retrain her body in some basic functions - speaking was slow, swallowing demanded conscious will. Eating was laborious and toileting was excruciating. Her liver was barely functioning and her belly became swollen, covered in an itchy rash. It was painful for her and painful to watch. Over the weeks that followed she began to recover. There was no talk of death or giving up. As she improved, she became aware of how slowly she was regaining her abilities and it dawned on her that making pots would be hard. This was said so simply but I knew the weight behind the words: 'I might never pot again'. The drive, the joy that would be excluded from her life as she matched masterful skill with challenges that drew her into a regular state of 'flow', a meditative yet driven state of mind that surpassed even the tipsy feeling she loved so much from the afternoon glass of wine or the late night spirits that helped her through sleepless nights and numbed her physical pain and deep sadness. I never knew which was the leading culprit from which she sought relief in the vaporous liquid. 
'I might never pot again' - another noun as verb. She never mentioned dying, but this was an admission of decay, a resignation to a life less living.

After 3 months she returned to the sleep of the half-dead, the comatose limbo, perhaps the gentlest way to leave us without having to say goodbye. That would have broken her heart. She loved us so hard and so deeply but suffered in the vulnerability that such love brings.

We are left with so many physical reminders of her: pots, blankets, jumpers, cups, bowls, plates, teapots, sculptures, planter pots, tiles and stained glass windows and stools and clothes and ... so many objects to remember her by, more laden now with significance, knowing that the seemingly endless tide of production is now ceased, de-ceased. I was with her when she died, as she exhaled her last, rattling breath. I saw her coffin descend into the cremation furnace. This prolific producer has been transformed by fire to ash and bone, just like the ash she used to put in the saggar firing to create beautiful blushes of soft pinks, greys and browns. That is what we should have done with her ashes! She would have loved (and I see her smile as I imagine too late) this functional use of her material form even in death. What delicate mushroom pinks she would have made. Instead, we spread her ashes in the creek at the beach, so they went to sand and salt, which form glazes, so whichever way you look at it she has merged with the elements of her making.

Sixteen years later, I have come back to the mud. After being seduced by other luminous fluids, I now feel able to get my hands into the mud again. I am back to the earth(1)y sludge of evolution. Through my making I express my difference and pay homage to my maternal legacy of making. My pots are not like my mother's. But, working with clay and slip is very much about my life with her, and I feel her presence keenly. I miss her in my making, but also revel in sharing the contentment of handling the cool, pliable earth; of moulding and making with mud.

And then there are the tools of a life of making that she left behind.

I inherited some potting equipment including her gas kiln, which, after so many years, is now functioning again. It goes like a rocket! I attend to late night firings, donning gloves and goggles, checking the temperature and listening out for exploding pots or falling shelves. So far, so good.

I grew up unaware that I need intellectual stimulation to be happy, and have often wondered why I felt restless and numb. I eventually cottoned on and now have enough mental stimulation to keep such discomforts at bay. I understand that I need ideas and challenges and so did my clever mother. Mud and making and art school helped her to survive the chops and the cleaning and washing nappies. It has taken time, but I have now made a life that combines making and ideas, and with mothering at the centre of everything. Underpinning all my work is a passion for materiality, for its capacity to shape experience through sensations of texture, weight, motion and space, for its articulation of connections between the body and the earth, between solid and liquid states, between personal experience and more enduring elements. Threads connect my creative and academic investigations back to memories of making with mud and my mother, then forwards, setting trajectories for future exploration. Like telegraph signals, humming back and forth along the wires, from me to her and back again, to my children and forwards to as yet unknown receivers of these messages - future generations, genetic or otherwise, who might inherit this potent drive for mud making. 
Now that the daily demands of parenting have eased enough for me to reflect, I am bursting with empathy for my mother - for her material dreaming and the tension that she lived between mothering and making, trying to excel at both, attempting an inner life amidst the demands of 5 children; for juggling loss and sadness with deep love for her children and a passion for her little pots that went out into the world on her behalf.

But I will never know her story as she lived it. It is too late for these conversations and connections.

I am left with the making, the mud ...

and my daughters.

\section{Reference List}

Ambrose, D 2009 'Deleuze, Philosophy and the Materiality of Painting', CV Boundas (ed), Gilles Deleuze: The Intensive Reduction, Continuum International Publishing Group, New York: 101-122 return to text

Carter, P 2004. Material Thinking: The Theory and Practice of Creative Research, Melbourne University Press, Melbourne return to text

Charny, D ed 2011 Power of Making: The Importance of Being Skilled, Victoria and Albert Museum and Crafts Council, London return to text

Csikszentmihalyi, M 1990 Flow: The Psychology of Optimal Experience, Harper \& Row, New York return to text

Haraway, D 2004 'Teddy Bear Patriarchy', The Haraway Reader, Routledge, New York return to text

Piper, G 2013 'The Visible and Invisible in Making: Reflecting on a personal practice', Studies in Material Thinking 9: https://www.materialthinking.org/papers/129 return to text

Tin, MB 2013 'Making Manifesto: Making and the sense it makes', Studies in Material

Thinking 9: https://www.materialthinking.org/papers/132 return to text

Vaughan, L 2007 'Material Thinking as Place Making', Studies in Material Thinking 1, 1:

https://www.materialthinking.org/papers/40 return to text

Dr Toni Roberts is a creative practitioner who works in a range of media including text, ceramics, polymers and spatial environments. Toni has a fascination with materials, water and the relationship between somatic sensation, materiality and imagination. Her work explores communication across non-fiction and fictive speculations in contexts that range from the museum to the ocean. Toni is a lecturer in the School of Media and Communication at RMIT and Director of Hatchling Studio.

\section{TEXT}

Vol 20 No 2 October 2016

http://www.textjournal.com.au

General Editor: Nigel Krauth. Editors: Kevin Brophy \& Enza Gandolfo

Creative works editor: Anthony Lawrence

text@textjournal.com.au 


\section{TEXT prose}

\section{Jane Downing}

\section{Let them eat brioche}

He gave up the pretense of being a flâneur the moment he caught sight of the awning that billowed ever-so gently over the café on the next corner. The lettering on the red canvas announced an irresistible destination and a flâneur, he knew because he'd read it, walked the streets at a saunter and stroll, idling the hours without purpose. He dashed across the intersection, purposeful of eye, set on a clear goal.

Jason Vickers, or just Vickers as he insisted on being called against equable Australian convention, had also been putting forward the character of an unrufflable young man. Me, a man of the boulevards, why yes. He'd repressed all excitement that this pavement was a boulevard in name too, namely the unpronounceable Saint-Germain-Des-Prés. He kept the fever under wraps even now as he took off his metaphorical flâneur boots, for what could be more natural, he assured himself, than a young man in Paris popping in for a morning coffee at the Café de Flore?

He followed ghosts through the awning-covered outdoor section of the café where women leaned across tiny tables, literally head touching head: têteà-tête. Aside from his dead heroes, he also followed a man in leathers and a motorbike helmet. The main door swung back toward him, an excluding gesture, and he paused and had to push his shoulder into the wood. Which felt brave.

In the time it took the biker to divest himself of his helmet, Vickers had the chance to look and to see. Of course he'd seen the photographs, but now the scene was in colour. The banquettes along the walls were red, as were the islands of benches on the floor, set around tables as tiny as school desks: perfect for writing on. A thick pillar in the centre held up the ceiling which harboured florettes of lights which were on, still, at 11 am because Paris was not bright in late November. All those artists going on about the quality of light knew something after all. Above the banquettes, mirrors: reflections of reflections of himself looked back at him. Into infinity he was tall and thin and bulked up with a long Sherlock coat. He closed his gawping fish-mouth.

Which wall would he ask to sit along to look most like a Sartre, a Hemingway or a Picasso, a Durrell, Capote, or those blokes whose names he couldn't spell or remember? A waiter took the choice from him and led him to the sidewall. He could sense the purr of cars outside on the road, while the room buzzed, the acoustics of a hive intensifying and dissipating conversations he wished he was part of.

The menu reminded him he couldn't speak, or read French. He scanned 
down, recognised the word 'brioche.' By lucky coincidence it was pretty much the cheapest thing on the menu too.

The waiter was still at his side. Their eyes met, assessed; Vickers resorted to the finger that knows everything and pointed to coffee then down to the brioche.

A nod, understood, then one word was offered in return: 'toasted?'

Vickers was sent into a fluster. Was it cool to have your brioche warm? Was it sophisticated to have it toasted or did this smack of the Nursery? Was the man in the long, white apron double tied around his waist, having a lend of another naïve tourist?

But toasted sounded lovely. Toast: Australia's national dish. Toasted brioche: a bit of comfort on a cold, ice-slippery day.

He took the risk: 'Oui.'

The waiter smiled for the first time, and gave a discreet thumbs up with both hands before turning and waddling toward the kitchen. His flippers flapped and his head bobbed. Other waiters on the floor rocked from foot to foot, their soft, white chests puffed, their beaks ready to sing, oui, oui, oui, all the way home, like a troop of Mary Poppins' penguins.

Vickers blinked them away. He stared down at the desk-sized table and tried to imagine the words that had been written here over the years. He ran his fingers over the wood, feeling for the Braille of time. The gods had left traces if only he could find them.

His thick cold fingertips itched for something else. He dug in his daypack for his notebook and pen. He flipped the former open like a TV detective, clicked the latter. His pen hovered. His lecturer said he had to let his imagination take flight - the cliché glutted hag. In the Café de Flore he could learn by osmosis.

He smelled deeply, willing the coffee toward him; had nothing to write without it, put his pen down.

Surreptitiously, Vickers checked out the habitués with quick glances sweeping faces, sweeping up images while pretending he was only keen on what was coming out of the clattering kitchen. He noted, in one sweep, the empty bottles piled at the entrance to the kitchen, indicating good times past.

Also: a white-haired man and a much younger woman passed handwritten pages between them at a table near the centre of the café. The word amanuensis leapt like a cricket into Vickers's head. He might not have more than a handful of French words, but he had pockets and pockets full of other words dying to get out. To the right of this pair, up against the back wall, was an older woman, field mouse innocuous, head bent over a similar mockleather notebook as his own. He didn't want to think about what she was writing, in case - for surely this was a possibility - it should be better than anything his imagination could conjure. So, where was his biker? A dark man in a three-piece suit sipped from a thimble of an espresso cup with one elbow resting on a motorbike helmet. Leathers slouched like a devoted dog at his feet.

Through all this sweeping, Vickers's eyes kept slipping away from one other man, the one in the corner, in the way you have to when confronted with the brightness of the sun. Vickers shifted his bottom on the banquette, 
squeaking slightly, to half face this irresistible presence. Chic. No figure could so perfectly embody this description.

'Monsieur,' the waiter coughed at his side.

Vickers put his notebook away self-consciously so the tray could fit, though he wanted to write this down immediately: to describe with love and longing the petite cup - speaking both French and English here - the miniature jugs, the big pat of butter. All the crockery was labelled just in case he'd forgotten he was sitting in the Café de Flore of Hemingway and Sartre and de Beauvoir and intelligent revolution in thinking. The jug with the coffee, the jug with the milk, the plate holding the pyramid of sugar cubes, all emblazoned proudly.

While engaged in an almost oriental ceremony of pouring and preparing - coffee, milk, sugar, stir, sip - his eyes kept slipping back on the magnet of chic. This was what a real vampire would look like: the symmetry of his face, the dark crescents of his eyelashes, the twitch of his thin lips as he half-smiled.

The smile, Vickers later recognised, heralded the transition in the morning from sequence to scene. The characters tramped onto the stage as Monsieur Chic's smile broadened to give a glimpse of sparkling teeth. Vickers disembodied himself to audience briefly then remembered himself, sipped the too-strong coffee, slathered butter on the carefully cut toasted brioche, watched from the wings, ie from the corner of his eyes.

A large Irishman had moved like a glacier through the café, knocking against the chair of the amanuensis, choosing a chair rather than the bench when he got to the corner table. He was Irish by evidence of his accent not his leprechaun green leather jacket. His voice was caramel and heather. It greeted while the vampire stood to air kiss, once, twice, the companion who'd washed along in his wake. The companion was American, horsey, blond, an accoutrement or an agent, Vickers couldn't decide, though he was absolutely, positively sure she was the accompaniment to a real, live writer. Who else keeps their grey hair long and in a ponytail, wears crumpled shirts, and dares that shade of green except someone who spends more hours than not in a world of his own creation?

Vickers was dabbling up the last crumbs of brioche on a wet index fingers when the writer's meeting at the corner table were served their breakfast. Dishes chattered as they jostled on the table, briefly drowning the preambles of talk. The woman devoured two boiled eggs with soldiers instantly, scoffing them down like a washerwoman - clearly unworried by the childish aspect of the skinny-cut toast. The writer left most of his omelette, though his muffin top tummy said this was a rare occurrence, and the Frenchman had a second French breakfast: another cup of espresso. Vickers poured what was left in the little jugs into his own little cup, ears burning. This was the life of a writer in his natural habitat.

A piece of paper was torn out of a notebook, little more than serviette sized, and the three drew on it in turns. The moment of conception? The mystery of creation? In a tricky glint of the florettes lighting, two carnivorous fangs extended over the Frenchman's thin lips. The suave vampire was determined to suck as much blood from the deal as he could: he wrote $51 \%$ on the apex of a triangle. There were answering nods. The horsey woman alluded to 'the people upstairs,' the writer to a degree of excitement at the opportunities, the woman cutting in to remind of the co-production aspects - 
point, stab at the triangle - and wasn't that Pixar; at least that's what Vickers was sure she said.

Vickers strained to glean any information on the story that was launching this juggernaut of commercial interest. He didn't have to. The tables were close - nothing was private and an ant could have jumped from their table to his without resorting to a 'Lion King' clawing and clasping at the edge. The real writer in his green leather could have read the small notes in Vickers's notebook about Shakespeare and Co., the bookshop not the creators, if he'd had any interest, which he obviously hadn't. But no, despite propinquity and strain, no indication of the story, only:

'I envisage six weeks post-production.'

'Twenty-five million.'

'Sponsorship imminent.'

'New York.'

The might of the marketplace had its own language. It did not sing. It did not dance, nor did it fight bulls or defeat the bourgeoisie.

Vickers watched the biker slip back into his leathers and leave. He imagined the small gasp of cold through the opened door reached him, though it didn't. The chill was all in his heart. He wrote down the word pilgrimage in his notebook, and the observation, better to be an atheist.

There was nothing left to milk from the jugs. The old woman on the back wall, Gertrude Stein upholstered, looked up as he rose, watched him with a frankly appraising look. The cashier in her golden cage on the other hand, hardly registered him through her thick black-rimmed Existential spectacles. He hand over $€ 10$ and got a little, a very little, change.

'Toilet?' he whispered.

The cashier's chin pointed up the spiral staircase to her left. Vickers climbed it stoutly remembering the moral of Hemingway's story about a café, albeit a Spanish one. It was all about maintaining dignity in the face of a frankly intolerable universe.

The upstairs room was empty, the banquettes and chairs expectant of a later crowd when the fire was lit. Vickers remembered reading about this room too. This was where the philosophers and writers worked, coming for the warmth and to escape heating bills in their Spartan apartments. With toilets handy too. Vickers locked himself in one of the cubicles so he could let the sadness of it all penetrate. In realism, as opposed to the fantasy of his ambitions, it was all about money. How to ensure the making of it. How to avoid the spending of it.

A china bowl sat on the bench by the bathroom sinks. Coins swam in the bottom like goldfish. Vickers hesitated. Was a tip part of the deal? The situation was beyond him, not something in his experience or ken. What was the sophisticated thing to do? Ah, that perennial question! A euro coin seemed too precious; nothing, too ungrateful. 
Cultural paralysis stopped him making a contribution. No one was watching though. He saw himself in the bathroom mirror and worried about his new moustache. Jumped at the shadow of a man.

This man behind him was a 'tall, handsome, muscular, broad-shouldered, brown-eyed, rosy-cheeked, square-jawed, soft-voiced young man.' Hemingway of course, exactly as his biographer Meyers described him in the days before writers were scared of adjectives.

'Boy,' Hemingway called Vickers, though he wasn't much more than a boy himself, in Paris in the 1920s. Vickers ignored him. Hemingway only talked to people like Woody Allen, not wannabes from the colonies. He pushed against the lavatory door.

'Boy,' Hemingway said again, completing his advice this time. 'Boy, there's no such thing as a free piss.'

Vickers scuttled away. Fuck the imagination. But he turned at the top of the vertiginous spiral of the stairs. Hemingway was propped against the mantelpiece now like a Bronte brother. There was authority in his broadshoulders and square-jaw. It was the authority that had author at its root. Vickers quailed, started back across the carpet; dug in his pocket for change.

Was it all about money though? Being a foreigner was so difficult. He felt a wave of homesickness for a land of sweeping plains and free public convenience networks.

It was then Jason found some kind of voice. He addressed Hemingway directly. 'You know mate, you should come to Australia. It's a whole different world.'

A shop further along the boulevard sold postcards. With his loose coins Jason bought shrunken reproductions of a couple of Toulouse-Lautrec posters. The great artist's work advertised concerts and confetti. Jason lent his daypack against his feet, rummaged about and found his notebook again. He stuck the postcards in the back of it so he'd always have something to remind him because he knew he'd forget - of the way of the world. Then he took up his flâneur boots, started to walk without destination.

Jane Downing has poetry and prose published in Australia and overseas. Her Doctor of Creative Arts is from UTS and she is a sessional teacher at Charles Sturt University, Albury campus.

TEXT

Vol 20 No 2 October 2016

http://www.textjournal.com.au

General Editor: Nigel Krauth. Editors: Kevin Brophy \& Enza Gandolfo

Creative works editor: Anthony Lawrence

text@textjournal.com.au 


\section{TEXT prose}

\section{Craig Jordan-Baker}

\section{The death of Patrice Nacullian}

It seems, to our lights now, that to write of a person or persons in a house, and a house made of brick no less, is a kind of abominable submission to the everyday. And so we put down our books or our tablets and sigh, even huff, at the naiveté of the writer. If by some chance we do not, then perhaps we are reading on a train and the person next to you looks like he is masturbating. No? Take a good look. Or perhaps you are experiencing in-air turbulence and you read these words merely to mollify the burgeoning images of fire, pressure-loss and the Mexican-wave of screams undulating down from the cockpit. You see how I try to entertain you?

This present tale is a desperate and fawning attempt by the author to please his audience, though the author must warn you that the tale involves persons in a house made of brick. It will be presently shown though that such a tawdry setting hides qualities that are in fact amusing and even enlightening, so the author begs your patience. You have committed yourself thus far, after all.

This brick house was a brick house in the city of Southampton. Three generations of the same family lived in this brick abode and if such a thing seems unlikely, please remember that this was the twentieth century, a time when people still lived together in relative harmony. This family was of Irish stock, Nan and Nandad Nacullian having crossed the waters from the Emerald Isle sometime after the Second World War, to help rebuild a country they were at best ambivalent towards. Nan Nacullian concentrated on pregnancy, smoking and crosswords, while Nandad Nacullian spent his days working and being racially abused on building sites. That of course was until the blacks came along, after which time Nandad Nacullian may as well have been Winston Churchill or Queen Victoria, he was considered so much like his English workmates.

Nan and Nandad Nacullian had four children: Betty, Bernard, Niall and Shannon. Niall died in Southampton General Hospital when he was two hours old from a lung defect that stumped the doctors and in her sixteenth year, Betty died suddenly, from suicide. So, only Bernard and Shannon were left and it was not long before Bernard, promising fellow that he was, became a builder's apprentice at the same firm as his father. Bernard soon fell prey to the wonderful sense of belonging that comes from racial abuse and smoking rollups. He tormented a Tobagan fellow by the name of Christian Lovejoy to such a degree that one day, Christian left a dogshit in Bernard's hardhat. Bernard 'shithead' Nacullian was quickly renamed amid general mirth, but they all beat Christian terribly anyway and left him in the shell of the new shopping centre. Everyone claimed he must have been drunk and slipped on a girder.

This leaves us with Shannon, who, after getting pregnant by her boss at the local chip shop, decided to retire to the bosom of the family home. The owner of the chip shop, James Radley, already had a wife and two children, so 
had no intention of acknowledging the newest outpouring of his fecund loins. Nan Nacullian was shocked as much by her daughter's stupidity as by the general shame that came from the assumption that Shannon was a whore, temptress, liar or fantasist. On the day Shannon's son Craig was born in Southampton General Hospital, Nan Nacullian was wistful at the thought of her own long-departed little boy and at that moment, crossing herself, she swore to protect her grandson, bastard or not. Amid all this family drama, Nandad Nacullian sat behind the fortress of his Daily paper, occasionally peering over its crenulations to ask for tea or that the radio be switched on.

Around this time, Nandad Nacullian was perplexed by the appearance of a third testicle in his ballsack, which he looked upon initially with vague suspicion and then with manly pride. You can imagine his embarrassment then when, after startling pangs of agony and months of malaise, he was told he had only weeks to live. He died five days after the prognosis, as much from awkwardness as the virulence of his cancer.

This left Nan Nacullian, Bernard, Shannon and Craig in the brick house in Southampton. At this point, the author recognises the need to move forward a decade or so, as very little changed in that house. You might say that time during this period was like a saveloy under a chip shop heat-lamp, close to closing time. That is, life looked pretty much as it always had, but it was somehow less appetising.

The saveloy analogy stops in 1999. One day in this year, Nan Nacullian announced she was bored with life and couldn't stand the thought of living into the twenty-first century, with all its things and all its stuff. There were enough things and stuff here in the twentieth century and she would be buggered, she said, if she would tolerate more things and stuff. All her life, she said, all her life she had seen an ever increasing mountain of things and stuff piling up in the back garden of existence and she had had enough. Therefore and with a definitive bob of her curly grey mane, she was resolved to die that evening in bed, after she had finished her customary cocoa and crossword.

The family, knowing of Nan Nacullian's lifelong Catholicism, questioned whether such a move meant suicide and if it did, how it was that she should square such a fact with her Creator, who did after all grant her the good fortune of life and free will. But Nan Nacullian would have none of it and waved away the suggestion like she waved away the ever-hopeful attempts of Mrs Craddock, the Avon lady, to ply her with creams and cosmetics (things and stuff). For Nan Nacullian did not intend to starve, overdose, hang, shoot, lacerate, immolate, eviscerate, suffocate or in any other way cause herself harm that would invalidate the sacred bond she shared with the Almighty.

'It will happen,' she said, 'as God intended.'

What this meant was, at the time of speaking, a mystery. Still, back in the twentieth century people still had respect for their elders and so did not move to question this solemn pronouncement. That night, which was a Tuesday, Nan Nacullian made faggots and gravy with mash, which the family ate in habitual silence around the small table in the lino-floored kitchen. Bernard had recently come home from the building site and was further-gone than usual, so much so that he slipped off his chair twice, before vomiting into his mash with one almighty heave. He spat his apologies through chunks of stomach-lining and gestured to Craig to help him upstairs. With a wince, Craig obeyed, if only because he wanted to get back to his meal as quickly as possible. 
'Can I have the stuff without vomit on?' he asked his mother on his return to the kitchen.

This was in fact the precise point where Nan Nacullian made her speech about things and stuff and intending to die that night. It was also a fact that it was only Craig who questioned the theological validity of her decision and whether it amounted to suicide or not, to which the old woman replied:

'It will happen as God intended.'

Shannon Nacullian had heard this phrase from her mother whenever something mildly upsetting came along. When the Labour landslide of 1997 threatened a descent into Godless communism, Nan Nacullian said that it would happen as God intended. When Bernard was up in court for GBH on Christian Lovejoy, the outcome was to be decided as God intended and when Shannon first told her mother that she was pregnant by James Radley, the chip shop owner, Nan Nacullian shook her head and then said:

'It will happen as God intended.'

This reliance on a single phrase throughout her life left those around her unmoved, for like death threats, antibiotics and the National Anthem, things which are used all the time, it ceased to be effective. As she rinsed the vomit and gravy from the dinner plates, Shannon Nacullian wondered abstractly what life without her mother would be like. With a sense of déjà vu, she realised she had no idea whatsoever.

'Did you leave your uncle Bernard on his side?' Shannon asked Craig.

'Yes, Mum.'

'Good. Isn't it your turn to do the drying up?' Shannon asked her son.

'No! It's Uncle Bernard's.' Craig remained at the table.

'So I'll just do it my fucking self then, shall I?'

Like the forming of the Himalayas as a result of the meeting between the Indo-Australian and the Eurasian plates, Craig rose up from the table and towards the kitchen sink.

Nan Nacullian eyed the backs of her descendants as they begrudgingly worked amid the post-prandial steam and bubbles. She was aware that the pronouncement of her end had had little effect on those around her. And so she said something she thought she never would.

'You remember that James Radley, Shannon?'

Shannon's water-wrinkled, soapy hands stopped.

'I said James Radley. You remember him?'

Craig turned quizzically to consider his mother's sudden lack of composure.

'What?' said Shannon.

'Ye deaf, daughter of mine? I'm sayin' to you, do ye remember that JAMES RADLEY?' 
'Owned the chippy down the hill yonks ago,' Shannon spat and she returned to the washing up.

'Yes, that's him. He's the one that gave ye Craig, didn't he?'

'What?' said Shannon.

'What?' said Craig, and dropped his gingham tea towel on the floor.

Nan Nacullian felt the warm thrill of success run through her. 'James Radley, there you go. He's yer Daddy so he is. And a fuckin' cunt of a man if God Almighty'll excuse me for saying so.'

'Mum!' shouted Shannon.

'Mum!' called Craig.

And then there was silence.

'And now, if you'll excuse me, I'm going to get ready for me bed. Craig, would ye bring up me cocoa in about a half hour, love?'

Craig's head moved upwards and then downwards several times. Shannon's wet hands dripped onto the lino. Nan Nacullian was gone.

An hour later, the lights went out for the evening, in the brick house in Southampton. Those that slumbered, slumbered, those that could not, did not. Outside, the Solent was bleeding into the English Channel. By midnight, Nan Nacullian was dead.

This then is the end. Though the author asks you to remember that if on approaching the end you hold fear, consider that you might have ended it before now, but no, you have committed yourself thus far, after all.

Craig Jordan-Baker is a writer and academic whose work has been published in New Writing, Potluck, Resurgence and elsewhere, as well as having many performances of his stage work. He is Subject Leader in creative writing at the University for the Creative Arts and Lecturer in creative writing at the University of Brighton.

\section{TEXT}

Vol 20 No 2 October 2016

http://www.textjournal.com.au

General Editor: Nigel Krauth. Editors: Kevin Brophy \& Enza Gandolfo

Creative works editor: Anthony Lawrence text@textjournal.com.au 